\title{
Job Satisfaction among Volunteers of the 2007 Special Olympics World Summer Games 2007世界夏季特殊奥林匹克運動會義工滿意度調查
}

\author{
Mei DU \\ Department of Physical Education, \\ Hong Kong Baptist University, HONG KONG \\ 杜 梅 \\ 香港浸會大學體育學系
}

\begin{abstract}
Volunteer contribution has been indispensable for successful sport events. Many studies have been conducted to understand motivations of volunteers. However, investigation of volunteer satisfaction for sports events has been left untouched. The present study attempted to make the first step in filling this research gap. Quantitative survey was conducted among 314 volunteers for 2007 Special Olympics World Summer Games. The results indicated that volunteers were nearly satisfied with their work $(\mathrm{M}=3.49, \mathrm{SD}=0.50)$. And they were more satisfied with the sense of "my contribution was valuable" ( $M=4.10, S D=0.82)$, "sense of achievement" $(M=4.00, S D=0.91)$, "I accumulated useful experience in the service" $(M=3.98$, $\mathrm{SD}=0.86)$ and "mutual support among colleagues" $(\mathrm{M}=3.92, \mathrm{SD}=0.87)$. Volunteers with very much knowledge about persons with ID tended to have significant higher satisfaction than those without or with little of certain knowledge ( $F=3.28$, df=2, $\mathrm{p}<.05)$. Volunteer job satisfaction was significantly associated with their perceived work stress $(\mathrm{r}=-.33, \mathrm{p}<.001)$. Volunteers who perceived lower stress tended to be more satisfied.
\end{abstract}

Keywords: volunteer, job satisfaction, stress, Special Olympics

\section{摘 要}

本研究旨在增加對體育賽事義工工作滿意度的認識。研究以問卷調查的形式進行, 收集了參與 2007 世界夏季特奧會的 314 名義工樣本。分析表明, 義工對於他們的工作幾近滿意 $(\mathrm{M}=3.49, \mathrm{SD}=0.50)$, 特別是對以下方面比較滿意: “我的付出是有價值 的” ( $\mathrm{M}=4.10, \mathrm{SD}=0.82)$ ，“有成就感” $(\mathrm{M}=4.00, \quad \mathrm{SD}=0.91)$ ，“我累積了有用的經驗” $(\mathrm{M}=3.98 ， \mathrm{SD}=0.86)$ ，和 “同事之間的相 互支持” $(\mathrm{M}=3.92, \mathrm{SD}=0.87)$ 。對智障人士有深刻認識的義工工作滿意度顯著高於有少許認識或沒有認識的義工 $(\mathrm{F}=3.28, \mathrm{df}=2$, $\mathrm{p}<.05)$ 。義工工作滿意度與工作壓力顯著相關（r=-.33，p<.001），壓力越低，滿意度越高。

關鍵詞 : 義工、工作滿意度、壓力、夏季特奧會

\section{Introduction}

Volunteers have been indispensable humane resources for many service-oriented not-for-profit organizations and large-scale events. According to the latest report issued in January, 2008 by the Department of Labor of the United States, during the year of 2006-2007 the total volunteer service within U.S. was about 3.16 billion hours. If every volunteer hour would have been paid the minimum wage, it would approximately cost US\$16.28 billion. Without volunteers, many non-profits would be hard to operate effectively. Regarding sport events, take Olympic Games as an example, 34,500 volunteers were recruited to work for the Barcelona Olympic Games, 60,000 for 
Atlanta Olympics, 47,000 for Sydney Olympics, 45,000 for Athens Games, and 100,000 for Beijing Olympics and Paralympics. It's unimaginable that how the Games would be like if without volunteer contributions. Sports events are usually very labor intensive. They rely very much on volunteers to provide a variety of essential services, such as liaison, transportation, translation, medical services. Just as Dr. Jacques Rogge, the President of International Olympic Committee, said, “... without [volunteers], sport and Olympism would be orphans. It would not be possible to organize the Olympic Games and competitions at all levels without volunteers' commitment and dedication" (2001, p. 1).

Due to the importance of volunteering, numerous research studies have been conducted to investigate the motives and barriers in volunteering (Auld, 2004; Chun, 2003; Liao-Troth, \& Dunn, 1999; Yeung, 2004). However, less light was shed on whether the volunteer experience was positive or negative. Whether volunteers feel satisfied or not with their work? What might contribute to their satisfaction? These issues were comparatively less investigated (Reeser, Berg, Rhea, \& Willick, 2005). Many management studies implied that job satisfaction was positively correlated with commitment, and job satisfaction was a significant predictor to turnover intention (e.g., Tett \& Meyer, 1993). Therefore, there is a crucial need to understand volunteer job satisfaction, hopefully to find out strategies to enhance commitment and retain good volunteers.

Especially for Special Olympics, who aims to provide sports training and competitions to persons with Intellectual Disabilities (ID), "relies on volunteers at all levels of the movement to ensure that every athlete is offered a quality sports training and competition experience" (Special Olympics, 2008). Allover the world, Special Olympics has received assistance from more than 700,000 volunteers which makes the movement possible and growing steadily and rapidly. In October, 2007, Special Olympics World Summer Games (SOSG) was held in Shanghai. 40,000 volunteers were recruited to serve the Games. Were they satisfied toward their service? What were the major areas that they were most satisfied or most dissatisfied? How could we measure their job satisfaction? What improvement could be made so as to enhance volunteer job satisfaction and retention? The present study aimed to find out the answers.

\section{Methods}

\section{Participants}

The SOSG 2007 recruited both overseas and local volunteers, but mainly local Chinese speaking residents of China, therefore, the participants of this study were a group of Chinese volunteers who served in the Games.

\section{Instrument}

The present study adopted a quantitative approach. A survey questionnaire was used for data collection. The questionnaire was composed of three sections. The self-developed Volunteer Job Satisfaction Scale (VJSS) consisted of 19 five-point Likert type items to measure job satisfaction, with 1 represented "very dissatisfied", 3 for "average" and 5 for "very satisfied". The VISS was developed on the basis of the Minnesota Satisfaction Questionnaire Short-form (1977) and the question items were modified based on the extensive literature review. Another section was the Perceived Stress Scale (PSS) developed by Cohen, Kamarck and Mermelstein (1983), which was a 14-item five-point Likert type scale with 1 representing "never experienced" and 5 representing "experienced very often". The last section was demographic information. The PSS was translated into Chinese because the target participants were all Chinese speaking. Back-translation method was used to ensure the scale content would be identical with the original.

The questionnaire was reviewed and piloted on 20 students with volunteer experience for layout and readability before actual data collection.

\section{Procedure for Data Collection}

The questionnaires were distributed to the participants by research assistants one to two days before the end of the volunteers' service period. They were asked to complete the questionnaires on site and then return to the research assistants. 


\section{Results}

\section{Demographics of Participants}

Among the 314 participants, there were 195 females, 119 males, and another 9 did not report their genders. In terms of age distribution, $85.4 \%(\mathrm{n}=268)$ were between 18 years old to 24 years old, $10.5 \%(\mathrm{n}=33)$ were between 25 years old to 34 years old. About 93.6\% (n = 294) were single. Students constituted 91.1\% ( $\mathrm{n}=286)$ of the sample and 5.1\% $(\mathrm{n}=22)$ were full-time job holders.
Amongst the participants, 78\% $(\mathrm{n}=245)$ reported having some knowledge about persons with intellectual disabilities (ID) before they applied to be volunteers and $20.7 \%(\mathrm{n}=65)$ did not have such knowledge.

Out of the 314 participants, $68.5 \%(\mathrm{n}=215)$ did not have any volunteer experience at all before the SOSG 2007 and $72.6 \%(\mathrm{n}=228)$ of them did not have any interaction with persons with ID prior the Games.

The total days the volunteers served in the Games varied from 1 day to 61 days depending on the job they were assigned to. Most of them worked from 5 to 14 days $(86.6 \%)$. The various job posts of the Games held by the participants is presented in Table 1 .

Table 1. Job Posts of the Participants during 2007 Special Olympics World Summer Games.

\begin{tabular}{lll}
\hline Job post & Frequency & Percent* \\
\hline Athletes accompany & 70 & 22.3 \\
Reception & 69 & 22.0 \\
Competition venue guide & 55 & 17.5 \\
Interpretation & 55 & 17.5 \\
Medical service & 28 & 8.9 \\
Messenger & 17 & 5.4 \\
Accommodation & 16 & 5.1 \\
Liaison & 15 & 4.8 \\
Referee assistant & 11 & 3.5 \\
Secretary & 4 & 1.3 \\
Tour guide & 4 & 1.3 \\
\hline
\end{tabular}

* Do not add up to $100 \%$ due to duplications.

\section{Reliabilities of the Scale}

The Cronbach's Alpha for the Volunteer Job Satisfaction Scale was .89, which indicated high internal consistency. The Perceived Stress Scale was a mature and frequently used reliable instrument for measuring perceived stress. The reported reliability coefficients from previous studies ranged from .76 to .86 (Cohen, et al., 1983; Khayat, 2007; Ramirez \& Hernandez, 2007). For the present study, the internal consistency was also acceptable (alpha $=.81$ ).

\section{Volunteer Job Satisfaction}

The results indicated that the general job satisfaction value was between "average" and "satisfied" $(\mathrm{M}=3.49$, $\mathrm{SD}=0.50)$, indicating the volunteers generally were nearly satisfied with the service in SOSG 2007.

No gender difference in job satisfaction level was found. However, significant difference was found among groups of without knowledge about persons with ID, with little knowledge, and with very much knowledge $(\mathrm{F}=3.28$, $\mathrm{df}=2, \mathrm{p}<.05)$. Volunteers with very much knowledge about persons with ID tended to have highest satisfaction with their service $(\mathrm{M}=3.64, \mathrm{SD}=0.56)$. 
Pearson Correlation test showed that volunteer job satisfaction was significantly associated with their perceived work stress $(\mathrm{r}=-.33, \mathrm{p}<.001)$. Volunteers who perceived lower stress tended to be more satisfied.

Descriptive analysis indicated that volunteers were more satisfied with the sense of "my contribution was valuable" $(\mathrm{M}=4.10, \mathrm{SD}=0.82)$, "sense of achievement" $(\mathrm{M}$
$=4.00, \mathrm{SD}=0.91)$, "I accumulated useful experience in the service" $(\mathrm{M}=3.98, \mathrm{SD}=0.86)$ and "mutual support among colleagues" $(\mathrm{M}=3.92, \mathrm{SD}=0.87$ ) (see Table 2). On the contrary, volunteers were less satisfied concerning "sufficient information about related schedule" $(\mathrm{M}=3.08, \mathrm{SD}=0.97)$ and "smooth communication with the management" $(\mathrm{M}=3.05$, $\mathrm{SD}=0.96)$.

Table 2. Volunteer Job Satisfaction of 2007 Special Olympics World Summer Games.

\begin{tabular}{lll}
\hline & Mean & SD \\
\hline My contribution was valuable & 4.10 & 0.82 \\
I had a sense of achievement in volunteering & 4.00 & 0.91 \\
I accumulated useful experience through the service & 3.98 & 0.86 \\
Mutual support with colleagues while in difficulties & 3.92 & 0.87 \\
My preparation & 3.85 & 0.78 \\
I enjoyed the process of volunteering & 3.83 & 0.87 \\
Cooperation of the participants & 3.77 & 0.76 \\
The fit between me and the allocated job & 3.58 & 0.83 \\
Working instructions for my post & 3.49 & 0.85 \\
Job allocation & 3.34 & 0.88 \\
Support received from relative departments while in difficulties & 3.25 & 0.87 \\
Being praised for good performance & 3.25 & 0.88 \\
Other welfares (e.g., uniform, meals, transportation) & 3.23 & 1.00 \\
Efficient information delivery & 3.22 & 0.95 \\
Training & 3.21 & 0.89 \\
Concern showed by the event organizers & 3.17 & 0.95 \\
Working time arrangement & 3.12 & 0.93 \\
Sufficient information about related schedule & 3.08 & 0.97 \\
Smooth communication with the management & 3.05 & 0.96 \\
\hline
\end{tabular}

\section{Discussions and Conclusion}

Generally, this study confirmes with previous research findings that volunteers were satisfied with their voluntary service in general (Dwiggins-Beeler, Spitzberg, \& Roesch, 2006, Luthy \& Schrader, 2007; Reeser, et al., 2005). The results implies that volunteers who already had very much knowledge about persons with Intellectual Disability prior the SOSG tend to feel more satisfied with their volunteer service. This shows how important it is to train volunteers before they embark on the work, especially for those who would work with individuals with certain special needs, such as individuals with ID, or with physical disabilities, and senior citizens. Because not all volunteers have opportunities to interact with people with special needs in their life, many of the volunteers, if not most, are not professionally trained to work with them. Therefore, sufficient training should be provided not only on the working procedures, role allocations during the events, but also on the characteristics of the service targets. It is essential not only for the success of the events, but also for the improvement of volunteer satisfaction, and more importantly, retention of them.

The present study finds that volunteers felt more satisfied in the following areas, "my contribution was valuable", "sense of achievement", "I accumulated useful experience in the service". These are more of feelings about overall volunteering experience. Such feelings indicate that generally volunteer service is interpreted as satisfying and beneficiary. This positive interpretation is helpful for retaining good volunteers. However, meanwhile, event organizers need to be highly aware of the less satisfying aspects, such as lack of information and 
inefficient communication between the volunteers and the management, which not only requires good volunteer training program but also sets higher requirements on volunteer coordinators. Coordinators are the persons who serve as bridges among volunteers and paid staff, and the management team. Well-trained coordinators are essential for any events involving large number of volunteers.

More over, since volunteers value personal gains and recognition very much (Reeser, et al., 2005), applying it to management practice, coordinators need to employ relative strategies to improve volunteers' sense of achievement, sense of being valuable and being recognized. Examples of such strategies are: say thank you, seek volunteers' advice in decision making, invitation of volunteer representatives to meetings, certificates award, giving them more autonomy and responsibilities, and so forth.

The finding of negative correlation between satisfaction and stress also gains support in the study of Dwiggins-Beeler, et al. (2005) that concluded if volunteers experience work stress, their overall satisfaction will be negatively affected. This is a warning message for event organizers that not only employed staff might experience working stress, even unpaid volunteers may feel under stress, and stress may lead to decreased job satisfaction. Volunteer stress is an issue that should be given more attention in volunteer management.

Since the success of sports event largely relies on volunteer input, it is of great importance for event organizers and volunteer coordinators to understand not only the motives of voluntary workers, but also the areas that they are more satisfied and areas they are less satisfied with, so that to enhance the ability of event organizers to recruit and retain good volunteers. Establishing an effective and efficient investigation method is one important step. Considering the large number of volunteer involvement, survey is a good choice. Nevertheless, though there is a considerable body of literature discussing volunteering motives or satisfaction in general, the research in sport events volunteering satisfaction in particular is sparse, saying nothing of the development of an instrument for measuring this. Therefore, another important attempt of this study is to pilot test an appropriate questionnaire to investigate volunteering satisfaction.
As suggested by Nunnally (1978), usually Cronbach's Alpha being .70 and above would be acceptable in social sciences research, the Volunteer Job Satisfaction Scale turns to be a reliable instrument. However, the establishment of a mature measurement requests more tests in larger samples to ensure its reliability and validity.

Despite the contribution to volunteer satisfaction research, the present study took a convenience sampling method which means the research findings may not be well applicable to the whole population. And the participants were volunteers for SOSG 2007 which was an international sport event, so the findings may not be generalized to long-term organizational volunteers.

\section{References}

Auld, C. (2004). Behavioral characteristics of student volunteers. Australian Journal on Volunteering, 9(2), 8-18.

Chun, H. (2003). A study of volunteers' motivation and satisfaction in the 2002 FIFA World Cup Korea Japan. United States Sports Academy, Daphne, Alabama.

Cohen, S., Kamarck, T., \& Mermelstein, R. (1983). A global measure of perceived stress. Journal of Health and Social Behavior, 24, 385-396.

Dwiggins-Beeler, R., Spitzberg, B., \& Roesch, S. (2006). Vectors of Volunteerism: Communication Correlates of Volunteer Retention, Recruitment, and Job Satisfaction in a Nonprofit Organization, The Annual Meeting of the International Communication Association. Dresden International Congress Centre, Dresden, Germany.

Khayat, R. A. (2007). Perceived stress, coping styles and periodontitis: A cross cultural analysis. The University of Michigan, Michigan.

Liao-Troth, M. A., \& Dunn, C. P. (1999). Social constructs and human service: Managerial sensemaking of volunteer motivation. Voluntas: International Journal of Voluntary and Nonprofit Organizations, 10(4), 345-361. 
Luthy, M. R., \& Schrader, R. (2007). Volunteer satisfaction: An analysis of contributing factors among hospic workers. Academy of Accounting and Financial Studies Journal, 11(special issue), 51-64.

Nunnally, J. (1978). Psychometric Theory. New York: McGraw-Hill.

Ramirez, M. T. G., \& Hernandez, R. L. (2007). Factor structure of the Perceived Stress Scale (PSS) in a sample from Mexico. The Spanish Journal of Psychology, 10(1), 199-206.

Reeser, J. C., Berg, R. L., Rhea, D., \& Willick, S. (2005). Motivation and satisfaction among polyclinic volunteers at the 2002 Winter Olympic and Paralympic Games. British Journal of Sports Medicine, 39, 20-24.

Rogge, J. (2001). Volunteerism. Olympic Review, December-January, 1.

Special Olympics. Volunteer. Retrieved May 27, 2008, from http://www.specialolympics.org/ Special+Olympics+Public+Website/English/Volunteer/ default.htm

Tett, R. P., \& Meyer, J. P. (1993). Job satisfaction, organizational commitment, turnover intention, and turnover: Path analyses based on meta-analytic findings. Personnel Psychology, 46(2), 259-293.

University of Minnesota. (1977). Minnesota Satisfaction Questionnaire. Minnesota: Vocational Psychology Research, University of Minnesota.

Yeung, A. B. (2004). The octagon model of volunteer motivation: Results of a phynomenological analysis Voluntas: International Journal of Voluntary and Nonprofit Organizations, 15(1), 21-46.

\section{Acknowledgments}

The author would like to extend her sincere thanks to Prof. Lena Fung, Department of Physical Education, Hong Kong Baptist University, for her data release and support in conducting the present study. The data were collected under the support of a Faculty Research Grant of Hong Kong Baptist University.

\section{Correspondence:}

Author's name: Dr. Mei DU

Affiliation: Department of Physical Education,

Hong Kong Baptist University,

Kowloon Tong, Hong Kong.

Telephone : (852) 3411-7720

Email : maydu@msn.com 